\title{
Screening for Iron Deficiency Anemia in Children Living at South Sinai, Egypt
}

\author{
By Gamal Abdel Naser Hasan Yamamah* \\ Nehal Salah Hasan \\ Asmaa Mahmoud Mohammed ${ }^{*}$
}

The objectives of this study are to assess prevalence of iron deficiency anemia in South Sinai children, in Egypt and to evaluate reliability of pin prick testing in anemia screening. A descriptive cross sectional study was conducted for children attending schools and nurseries living in 6 districts in South Sinai through multistage random sampling. 1,828 children of both genders were selected. Pin prick screening showed that $37.7 \%$ of children had mild to moderate degrees of anemia. There was significant difference among examined districts $(p<0.0001)$. Anemia was less prevalent among children aging $10-<15$ years, in children with history of parental consanguinity and in children with Bedouin origin $(p<0.01)$. Gender had no effect on anemia rates. Severe anemia was present only in 3 children. Complete blood count test matched pin prick results and showed that $61.5 \%$ of anemic children had microcytic hypochromic red blood cells (RBCS). Median serum ferritin was below normal $(12.5 \mu \mathrm{g} / \mathrm{dl})$ and depleted iron stores were present in 53\% of examined children. Depletion was more in females $(p<0.05)$. Iron deficiency anemia is a health problem among South Sinai children. Screening program is needed. Pin prick hemoglobin testing is simple, cheap and reliable.

Keywords: Children, Egypt, Hemoglobin (Hb), Iron deficiency anemia (IDA), Pin prick testing

\section{Introduction}

Iron deficiency anemia (IDA) is one of the most important nutritional deficiencies affecting various socioeconomic strata. IDA is more common in developing countries, with children and adolescents being at a significantly higher risk for the condition (De Andrade Cairo et al. 2014). Anemia remains the most prevalent nutritional disorder among women and children in the Middle East and North Africa region (Austin et al. 2012).

South Sinai is an arid area (Abdelkader 2005). It is located at North East region of Egypt. People living at South Sinai have environmental, climatic, social and ethnic specifications that are markedly different from other areas in Nile valley. Political and military events lead to lack of health surveys. To our knowledge, no comprehensive medical study was mediated for South Sinai children. Since 2005, a school meal (in the form of iron fortified biscuits) is provided for school children 5 days per week throughout the school year. However, many of children refuse to eat it for its unpleasant taste.

\footnotetext{
* Pediatrics Department, National Research Centre, Egypt.

${ }^{\dagger}$ Clinical and Chemical Pathology department, National Research Centre, Egypt.

* Occupation and Environmental Medicine department, National Research Centre, Egypt.
} 
The importance of anemia as a public health issue in both developing and developed nations is well known. The World Health Organization estimates that around two billion individuals worldwide are anemic (WHO, 2011). Iron deficiency anemia was estimated to be $7.4-9.5 \%$ in Korea as described by Korean Ministry of Health and Welfare (2013). Iron deficiency anemia is more prevalent in developing countries compared to developed countries. CDC (2002) stated that in developed countries it affects $4.3-20 \%$ of the population, while in developing countries these figures range from $30-48 \%$.

Iron deficiency (ID) is the most common nutritional deficiency worldwide (Killip et al. 2010). It is a major cause of morbidity and mortality that is responsible for the majority of cases of anemia (Lee et al. 2014).

ID prevalence is not known for most countries due to the high cost of the biochemical tests required to define precisely an individual's iron status. The prevalence of anemia is commonly used as an indirect indicator for iron deficiency, based on the assumption that about $50 \%$ of all cases of anemia are iron deficient (Mclean et al. 2009).

IDA can cause reduced work capacity in adults and impact motor and mental development in children and adolescents. It may affect visual and auditory functioning and is weakly associated with poor cognitive development in children (Killip et al. 2010).

\section{Objectives}

We aimed to assess the prevalence of iron deficiency anemia among South Sinai children and detect possible risk factors. We also aimed to evaluate the pin prick test for hemoglobin as a reliable screening test.

\section{Subjects and Methods}

Study design: A descriptive cross sectional study was conducted on sample of children.

Sampling and sample size: A multistage stratified random sampling technique was used to select a sample of children attending governmental schools and nurseries in 6 districts including cities and surrounding Bedouin settlements in South Sinai governorate. Stratified selection of children was mediated taking in consideration age, gender, site and ethnic variations in South Sinai.

The representative sample size was calculated using the automated method that depends on the population size, desired confidence level and confidence interval (Dawson-Saunders and Trapp 1994). The formula used was:

$$
\text { Sample Size }=\frac{\left(\mathrm{Z}^{2}\right) *(\mathrm{P}) *(1-\mathrm{P})}{\mathrm{C}^{2}}
$$

where:

$\mathrm{Z}=\mathrm{Z}$ value (standard value 1.96 for $95 \%$ confidence level); 
$\mathrm{P}=$ percentage picking a choice, expressed as decimal ( 0.5 used for sample size needed);

$\mathrm{C}=$ confidence interval, expressed as decimal (2.2 in this study).

The calculated sample size was 1,823 child at $95 \%$ confidence level and confidence interval $=2.2$. The study included 1,828 child representing all the 6 areas of South Sinai. We considered site and population number for stratification. Number of children in each site was as follows; Tur $(9,655)$, Redeia $(3,778)$, Zeneima $(2,690)$, Sidre $(5,838)$, St. Kathrene $(2,071)$, Nuewaa $(4,012)$ (Figure 1). Population data are available in South Sinai website ${ }^{1}$.

Figure 1. Map of Egypt's Sinai Peninsula (the arrows point to the studied areas)

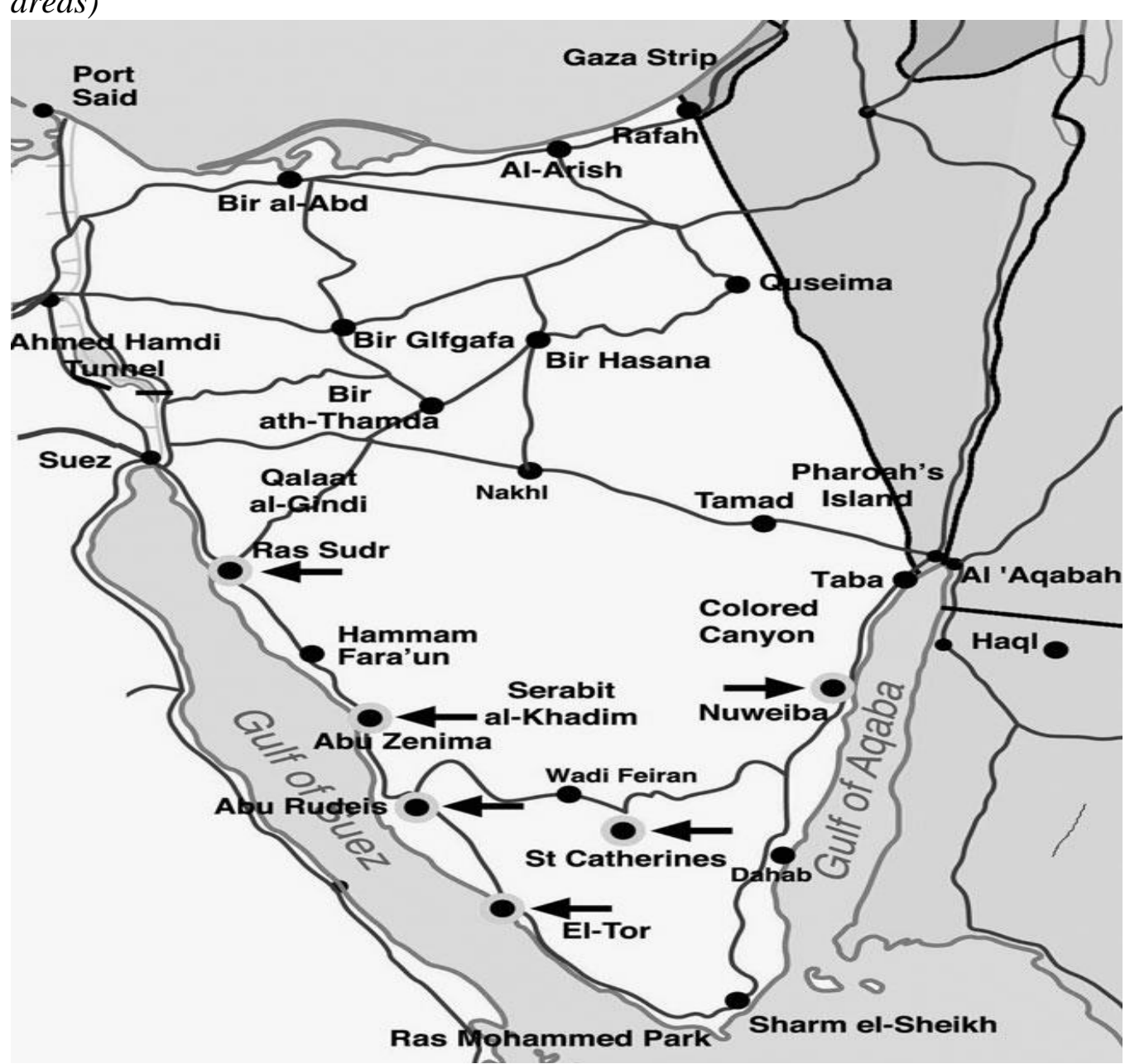

Source: http://www.allsinai.info/bilder/maps/sinai04-b.jpg (no copyright indicated).

Study subjects were 889 girls and 939 boys. Their age ranged between 2.717.8 years $($ Mean $\pm \mathrm{SD}=10.6 \pm 3.1$; Median=10.3).

Methods: a. Approval of National Research Centre Ethical committee was obtained and explanation about the study was provided for children care givers

${ }^{1}$ See: South Sinai website: http://www.South.Sinai.gov.eg. 
and school teachers before examination and blood sampling was conducted; $\mathbf{b}$. Personal data was collected (birth date to calculate age, gender, residence and ethnic origin); c. Anthropometric measures were recorded (weight and height) using standard techniques and highly sensitive balance and scale (SECCA apparatus, with scale grading $(00.00 \mathrm{Kg})$. Body Mass Index (BMI) was calculated according to standard equation: $\mathrm{BMI}=\mathrm{Weight}(\mathrm{Kg}) / \mathrm{Height}\left(\mathrm{m}^{2}\right)$; d. Screening for anemia status: blood sample was withdrawn from tip of a finger after disinfection through pin prick, $200 \mu \mathrm{l}$ of blood was collected in an eppendorf tube. Hemoglobin was determined to 1,828 subjects by hemoglobin cyanide method and measured in a spectrometer at a wavelength of $540 \mathrm{~nm}$ (Van Assendelft 1977). Four ml of venous blood samples were withdrawn from 349 subjects. Two $\mathrm{ml}$ were withdrawn on EDTA containing vacutainer and the other two ml were withdrawn on plain vacutainer. EDTA blood was used for measurement of complete blood count (CBC), while serum was obtained after blood centrifugation and used to measure serum ferritin and transferrin for 100 subjects. Transferrin percent saturation was calculated according to standard equation; e. Complete blood count (CBC) was performed to 349 subjects by Medonic hematology analyzer (CBC 2012); f. Serum ferritin was measured by ELISA technique using the kit provided from Immunospec (IMMUNOSPEC CORPORATION 7018 Owensmouth Ave. Suite \# 103 Canoga Park, C.A. 91303). Serum ferritin was considered below normal according to WHO values (WHO 2011); g. Serum transferrin was measured by ELISA technique using kit provided from Abcam Inc (Cambridge, MA 02139-1517, USA). Trasferrin percent saturation was calculated and values $<20$ were considered below normal (www. Pubinfo.vacu 2010). WHO Hemoglobin thresholds classification for anemia degrees was applied to our data (WHO 1989); h. Data manipulation and statistical analysis: the collected data and the clinical results have been computerized and coded using SPSS version 18.0 (Statistical Package for Social Science) and statistically analyzed. Quantitative data was expressed as mean values \pm standard deviation (SD). Ranges and frequency of distributions were estimated for quantitative variables. Normally distributed data was compared using Student's t-test for 2 groups and ANOVA test for more than 2 groups. On the other hand, non-parametric tests were used for abnormally distributed data. Significance level of 0.05 is used. The significance of differences between proportions was tested by the Chi-square test $\left(\chi^{2}\right)$. Differences were considered significant with $p$-value $\leq 0.05$. Logistic regression analysis was performed to predict the presence or absence of outcome based on a set of predictor values. Odds ratios and their $95 \%$ CI for significantly associated factors were reported.

\section{Results}

Using the WHO classification for anemia degrees according to age and gender (WHO 1989), studied subjects were classified into normal or anemic. Those with anemia were categorized into mild, moderate or severe anemia. In the present work, the overall prevalence of anemia among studied children 
$(1,828)$ in all districts under study was $37.9 \%$. Mild anemia accounted $22 \%$ and moderate anemia accounted $15.7 \%$. Only 3 cases had severe anemia, two from El-Tur and one from Redeis. They had history of thalassemia (Table 1).

Higher prevalence of anemia were observed in Sidre and Nuweibaa (45.3\% and $43.7 \%$, respectively) compared to lower values in Zeneima (37.5\%), El-Tur (36.2\%), Redeis (35.1\%) and St. Kathrene (23.1\%) with Statistical significant difference between areas ( $p$-value<0.0001) (Table 1).

Table 1. Prevalence of Anemia among Screened Children and Effect of Residence

\begin{tabular}{|c|c|c|c|c|c|c|c|}
\hline \multirow[b]{2}{*}{$\begin{array}{l}\text { Anemia status } \\
\text { by hemoglobin } \\
\text { level }(\mathrm{g} / \mathrm{dl})\end{array}$} & \multicolumn{6}{|c|}{ The District Under Study } & \multirow[b]{2}{*}{$\begin{array}{c}\text { Total } \\
\underset{(\%)}{f}\end{array}$} \\
\hline & $\begin{array}{c}\text { El-Tur } \\
\underset{(\%)}{f} \\
\end{array}$ & $\begin{array}{c}\text { Redeis } \\
f \\
(\%) \\
\end{array}$ & \begin{tabular}{|c|}
$\begin{array}{c}\text { Zeneima } \\
f \\
(\%)\end{array}$ \\
\end{tabular} & $\begin{array}{c}\text { Sidre } \\
\boldsymbol{f} \\
(\%)\end{array}$ & $\begin{array}{c}\text { St. Kathrene } \\
f \\
(\%) \\
\end{array}$ & $\begin{array}{c}\text { Nuweibaa } \\
f \\
(\%) \\
\end{array}$ & \\
\hline Normal & $\begin{array}{c}271 \\
(63.8)\end{array}$ & $\begin{array}{c}146 \\
(64.9)\end{array}$ & $\begin{array}{c}105 \\
(62.5)\end{array}$ & $\begin{array}{c}203 \\
(54.7)\end{array}$ & $\begin{array}{c}187 \\
(76.9)\end{array}$ & $\begin{array}{c}223 \\
(56.3)\end{array}$ & $\begin{array}{l}1,135 \\
(62.1)\end{array}$ \\
\hline Mild anemia & $\begin{array}{c}77 \\
(18.1)\end{array}$ & $\begin{array}{c}44 \\
(19.5)\end{array}$ & $\begin{array}{c}44 \\
(26.2)\end{array}$ & $\begin{array}{c}101 \\
(27.2)\end{array}$ & $\begin{array}{c}38 \\
(15.7)\end{array}$ & $\begin{array}{c}98 \\
(24.8)\end{array}$ & $\begin{array}{c}402 \\
(22.0)\end{array}$ \\
\hline Mod. anemia & $\begin{array}{c}76 \\
(17.9)\end{array}$ & $\begin{array}{c}33 \\
(14.7)\end{array}$ & $\begin{array}{c}19 \\
(11.3)\end{array}$ & $\begin{array}{c}67 \\
(18.1)\end{array}$ & $\begin{array}{c}18 \\
(7.4)\end{array}$ & $\begin{array}{c}75 \\
(18.9)\end{array}$ & $\begin{array}{c}288 \\
(15.7)\end{array}$ \\
\hline Severe anemia & $\begin{array}{c}1 \\
(0.2)\end{array}$ & $\begin{array}{c}2 \\
(0.9)\end{array}$ & $\begin{array}{c}0 \\
(0.0)\end{array}$ & $\begin{array}{c}0 \\
(0.0)\end{array}$ & $\begin{array}{c}0 \\
(0.0)\end{array}$ & $\begin{array}{c}0 \\
(0.0)\end{array}$ & $\begin{array}{c}3 \\
(0.2)\end{array}$ \\
\hline All anemia & $\begin{array}{c}154 \\
(36.2)\end{array}$ & $\begin{array}{c}79 \\
(35.1)\end{array}$ & $\begin{array}{c}63 \\
(37.5)\end{array}$ & $\begin{array}{c}168 \\
(45.3)\end{array}$ & $\begin{array}{c}56 \\
(23.1)\end{array}$ & $\begin{array}{c}173 \\
(43.7)\end{array}$ & $\begin{array}{c}693 \\
(37.9)\end{array}$ \\
\hline Total & $\begin{array}{c}425 \\
(100)\end{array}$ & $\begin{array}{c}225 \\
(100)\end{array}$ & $\begin{array}{c}168 \\
(100)\end{array}$ & $\begin{array}{c}371 \\
(100)\end{array}$ & $\begin{array}{c}243 \\
(100)\end{array}$ & $\begin{array}{c}396 \\
(100)\end{array}$ & $\begin{array}{l}1,828 \\
(100)\end{array}$ \\
\hline
\end{tabular}

Notes: $\chi^{2}=57, \mathrm{df}=15, \mathrm{p}$-value $<0.0001 *$.

Source: Authors' estimations.

Age group $10-<15$ years had the least prevalence of anemia $(32.8 \%)$ compared to other studied age groups that had anemia ranging between $41.3 \%$ and $42.0 \%$. The difference was statistically significant $(\mathrm{p}<0.0001)$ (Table 2).

Table 2. Effect of Age Group on Prevalence of Anemia among Screened Children

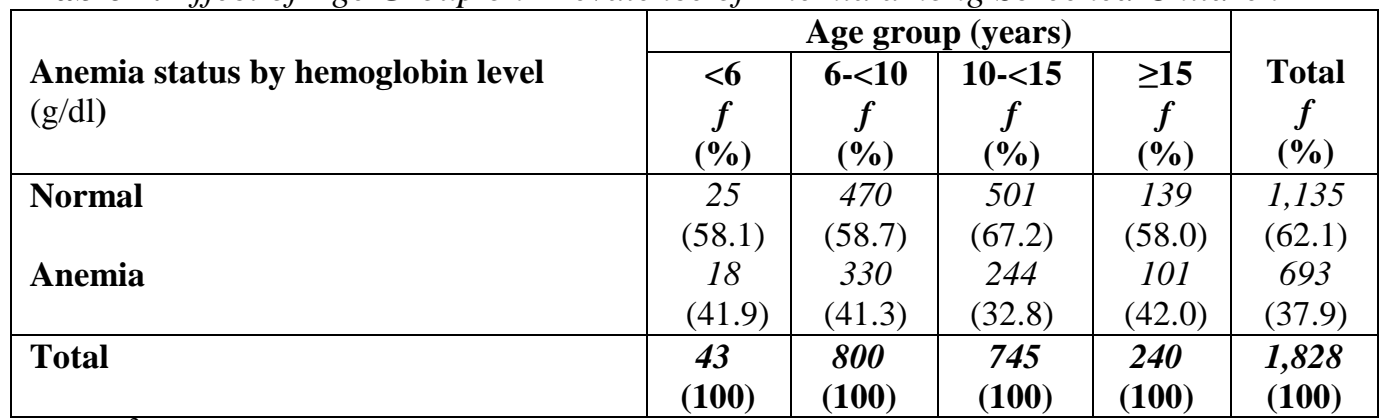

Note: $\chi^{2}=68.7, \mathrm{df}=9, \mathrm{p}$-value $<0.0001 *$.

Source: Authors' estimations.

Among the studied children, 615 had history of positive parental consanguinity and 783 had negative history. Meanwhile, 430 could not give a conclusive history. Children with history of positive consanguinity had less prevalence of anemia (34.6\%). On the other hand, those with negative history 
had higher values $(38.4 \%)$. The difference between the 2 groups was significant $(\mathrm{p}=0.008) .853$ of the examined children were of Bedouin origin, while 975 were coming from other urban regions of the Nile Valley. Those of Bedouin origin had less prevalence of anemia (35.5\%) compared to children of urban origin $(40.0 \%)$. The difference was statistically significant $(\mathrm{p}=0.008)$. Males were 939 of the studied subjects with anemia prevalence of $39.0 \%$, while females were 889 with anemia prevalence of $36.7 \%$. Males had higher levels of anemia but gender seems to have no statistical difference $(\mathrm{p}=0.6)$ (Table 3).

Table 3. Effect of Consanguinity, Ethnic Origin and Gender on Anemia Prevalence

\begin{tabular}{|c|c|c|c|c|c|c|c|c|}
\hline \multirow{2}{*}{$\begin{array}{l}\text { Anemia } \\
\text { status by } \\
\text { hemoglobin } \\
\text { level (g/dl) }\end{array}$} & \multicolumn{3}{|c|}{ History of consanguinity } & \multicolumn{2}{|c|}{ Ethnic origin } & \multicolumn{2}{|c|}{ Gender } & \multirow[b]{2}{*}{$\begin{array}{c}\text { Total } \\
\underset{(\%)}{f}\end{array}$} \\
\hline & $\underset{(\%)}{\mathbf{N} / A}$ & $\begin{array}{c}\text { Yes } \\
f \\
(\%)\end{array}$ & $\begin{array}{c}\text { No } \\
f \\
(\%)\end{array}$ & $\begin{array}{c}\text { Urban } \\
\underset{(\%)}{f}\end{array}$ & $\underset{(\%)}{f}$ & $\underset{(\%)}{f}$ & $\begin{array}{c}\text { Female } \\
\underset{(\%)}{f}\end{array}$ & \\
\hline \multirow[t]{2}{*}{ Normal } & $\begin{array}{c}251 \\
(58.4)\end{array}$ & $\begin{array}{c}402 \\
(65.4)\end{array}$ & $\begin{array}{c}482 \\
(61.6)\end{array}$ & $\begin{array}{c}585 \\
(60.0)\end{array}$ & $\begin{array}{c}550 \\
(64.5)\end{array}$ & $\begin{array}{c}572 \\
(61.0)\end{array}$ & $\begin{array}{c}563 \\
(63.3)\end{array}$ & $\begin{array}{l}1,135 \\
(62.0)\end{array}$ \\
\hline & $\begin{array}{c}179 \\
(41.6)\end{array}$ & $\begin{array}{c}213 \\
(34.6)\end{array}$ & $\begin{array}{c}301 \\
(38.4)\end{array}$ & $\begin{array}{c}390 \\
(40.0)\end{array}$ & $\begin{array}{c}303 \\
(35.5)\end{array}$ & $\begin{array}{c}367 \\
(39.0)\end{array}$ & $\begin{array}{c}326 \\
(36.7)\end{array}$ & $\begin{array}{c}693 \\
(37.9)\end{array}$ \\
\hline \multirow[t]{2}{*}{ Total } & $\begin{array}{c}430 \\
(100)\end{array}$ & $\begin{array}{c}615 \\
(100)\end{array}$ & $\begin{array}{c}783 \\
(100)\end{array}$ & $\begin{array}{c}975 \\
(100)\end{array}$ & $\begin{array}{c}853 \\
(100)\end{array}$ & $\begin{array}{c}939 \\
(100)\end{array}$ & $\begin{array}{c}889 \\
(100)\end{array}$ & $\begin{array}{l}1,828 \\
(100)\end{array}$ \\
\hline & \multicolumn{3}{|c|}{$\begin{array}{c}\text { p-value }=0.008 \\
\chi^{2}=17.3 \\
\mathrm{df}=6\end{array}$} & \multicolumn{2}{|c|}{$\begin{array}{c}\text { p-value }=0.008 \\
\chi^{2}=7.9 \\
\mathrm{df}=3\end{array}$} & \multicolumn{2}{|c|}{$\begin{array}{c}\text { p-value }=0.6 \\
\chi^{2}=1.6 \\
\mathrm{df}=3\end{array}$} & \\
\hline
\end{tabular}

Source: Authors' estimations.

A trial for detection of anemia risk factors that may contribute to the development of anemia among South Sinai children was mediated. A binomial logistic regression analysis was performed on anemia as an outcome and 13 predictors to predict the factors that may be associated with the increased probability of anemia among screened children. All available predictors were involved in the equation (residential location of the city, consanguinity, gender, origin, age, weight, height, stature degree (normal, tall or short), BMI, height for age $\mathrm{z}$ score, height for age percentile, weight for age $\mathrm{z}$ score and weight for age percentile.

Only residential location of the city (area) and height for age percentile add significantly to the model prediction of anemia among screened children $(\mathrm{OR}=2.4,1.01$ respectively) ( $\mathrm{p}$-value $<0.05)$. Difference in anemia prevalence in different cities could be explained by ethnic origin. Bedouin inhabitants of each area descend from different tribes and have different dietary habits. Furthermore, higher prevalence of anemia in certain areas means that they should have priorities for applying health education, supplementation or fortification programs to combat anemia in the future.

On the other hand, gender, consanguinity, origin, age, weight, BMI, height, height for age $\mathrm{z}$ - score, stature, weight for age $\mathrm{z}$ score and weight for age percentile of screened children did not add significantly to the model prediction of anemia ( $\mathrm{p}$-value $>0.05$ ). 
Complete blood count (CBC) was done for a subsample of 349 subjects by Medonic hematology analyzer. Table 4 presents values of hemoglobin $(\mathrm{g} / \mathrm{dl})$, RBCs count (million/ $\mu \mathrm{l})$, white blood cells count (x $\left.10^{3} / \mu 1\right)$, hematocrit $(\%)$, Mean Corpuscular Volume (MCV), Mean Corpuscular Hemoglobin (MCH), Mean Corpuscular Hemoglobin Concentration (MCHC) and platelet count (x $\left.10^{3} / \mu 1\right)$.

Present data proved that 129 out of 349 were anemic $(36.96 \%)$. CBC results showed that the mean hemoglobin concentration was $11.8 \pm 1.0 \mathrm{~g} / \mathrm{dl}$, ranging between 5.2 and $15.0 \mathrm{~g} / \mathrm{dl}$. Age group $10-<15$ years had values of hemoglobin $(12.1 \mathrm{~g} / \mathrm{dl})$ and hematocrit $(37.8 \%)$ higher than other age groups $(\mathrm{p}<0.002$ and $\mathrm{p}<0.04$, respectively). The difference was statistically significant $(\mathrm{p}=0.002$ and $\mathrm{p}=0.04$, respectively). Anemia among Bedouins accounted $31 \%$ compared to $40 \%$ of urban origin (Table 4 ).

Table 4. CBC Parameters of 349 Children According to their Age Groups

\begin{tabular}{|l|c|c|c|c|c|}
\hline \multirow{2}{*}{$\begin{array}{l}\text { Parameter } \\
(\mathbf{m e a n} \pm \text { SD) }\end{array}$} & \multicolumn{5}{|c|}{ Age group (years) } \\
\cline { 2 - 6 } Hemoglobin $(\mathbf{g} / \mathbf{d l})$ & $11.6 \pm 0.8$ & $11.6 \pm 0.8$ & $12.1 \pm 1.1$ & $11.5 \pm 1.8$ & $0.002^{*}$ \\
\hline RBCs $(\mathbf{m i l l i o n} / \boldsymbol{\mu l})$ & $4.5 \pm 0.37$ & $4.6 \pm 0.38$ & $4.6 \pm 0.4$ & $4.7 \pm 0.6$ & 0.2 \\
\hline WBCs $(\mathbf{X 1 0} / \boldsymbol{\mu l})$ & $8.8 \pm 3.4$ & $7.7 \pm 2.1$ & $6.8 \pm 1.8$ & $6.2 \pm 1.2$ & $<0.0001^{*}$ \\
\hline HCT (\%) & $36.3 \pm 2.5$ & $36.3 \pm 0.2$ & $37.8 \pm 5.9$ & $37.1 \pm 5.6$ & $0.04^{*}$ \\
\hline M.C.V (fl) & $79.2 \pm 3.3$ & $78.6 \pm 5$ & $80 \pm 8.8$ & $80.2 \pm 10$ & 0.3 \\
\hline M.C.H $(\mathbf{p g})$ & $26.4 \pm 1.4$ & $26.5 \pm 4.1$ & $27 \pm 2.4$ & $28.1 \pm 10$ & 0.3 \\
\hline M.C.H.C $(\mathbf{g} / \mathbf{d l})$ & $33.6 \pm 1.7$ & $33.4 \pm 1.3$ & $33.2 \pm 1.3$ & $31.8 \pm 2$ & $<0.0001^{*}$ \\
\hline Platelet $(\mathbf{X 1 0} / \boldsymbol{\mu l})$ & $292 \pm 80.7$ & $290.7 \pm 67.3$ & $270.8 \pm 59.3$ & $247.7 \pm 65.2$ & $0.002^{*}$ \\
\hline
\end{tabular}

Source: Authors' estimations.

Data of $\mathrm{CBC}$ was very close and comparable to results obtained by pin prick testing. Age group 10-<15 years has the least prevalence of anemia by both tests. Among anemic children, $61.5 \%$ were microcytic hypochromic indicating prolonged iron deficiency. Iron deficiency anemia is well known as microcytic anemia.

Further subsample of 100 subjects was tested for serum ferritin and transferrin levels. Transferrin saturation was then calculated. Median serum ferritin was below 15 in all studied age groups and transferrin saturation was below 20 indicating marked depletion of iron stores in studied children. No age difference was detected (Table 5). Decrease in serum ferritin is one of the earliest signs of iron deficiency. 
Table 5. Ferritin and Transferrin of 100 Children According to their Age Groups

\begin{tabular}{|c|c|c|c|c|c|}
\hline \multirow[b]{2}{*}{ Parameter } & \multicolumn{5}{|c|}{ Age group (years) $n=100$} \\
\hline & $\begin{array}{c}<6 \\
(n=6)\end{array}$ & $\begin{array}{l}6-<10 \\
(n=32)\end{array}$ & $\begin{array}{l}10-<15 \\
(n=56)\end{array}$ & $\begin{array}{c}\geq 15 \\
(\mathbf{n}=6)\end{array}$ & p-value \\
\hline $\begin{array}{l}\text { Ferritin }(\boldsymbol{\mu g} / \mathbf{l}) \\
(\text { Mean } \pm \text { SD) } \\
\text { Median }\end{array}$ & $\begin{array}{c}15.1 \pm 8.4 \\
13\end{array}$ & $\begin{array}{c}23.9 \pm 19.6 \\
12.5\end{array}$ & $\begin{array}{c}21.6 \pm 17.7 \\
13\end{array}$ & $\begin{array}{c}16.5 \pm 9.2 \\
12\end{array}$ & $\begin{array}{l}>0.05 \\
>0.05\end{array}$ \\
\hline $\begin{array}{l}\text { Transferrin } \\
(\text { Mean } \pm \text { SD) } \\
\text { Median }\end{array}$ & $\begin{array}{c}289 \pm 68 \\
284\end{array}$ & $\begin{array}{c}279 \pm 57 \\
280\end{array}$ & $\begin{array}{c}291.7 \pm 62 \\
297\end{array}$ & $\begin{array}{c}304 \pm 53 \\
299\end{array}$ & $\begin{array}{l}>0.05 \\
>0.05\end{array}$ \\
\hline $\begin{array}{l}\text { Transferrin } \\
\text { Saturation (\%) }\end{array}$ & 12.6 & 14.8 & 12.5 & 11.8 & $>0.05$ \\
\hline
\end{tabular}

Source: Authors' estimations.

$53 \%$ of studied children had iron stores depletion. More depletion was present among females $(66.0 \%)$ compared to males $(41.5 \%)$ with significant difference $(\mathrm{p}=0.014)$ (Table 6).

Table 6. Depleted Iron Stores by Age Group and Gender Among Screened Children

\begin{tabular}{|c|c|c|c|c|c|c|c|}
\hline \multirow[b]{2}{*}{$\begin{array}{l}\text { Iron stores status by } \\
\text { ferritin level (ng/ml) }\end{array}$} & \multicolumn{4}{|c|}{ Age group (years) } & \multicolumn{2}{|c|}{ Gender } & \multirow[b]{2}{*}{$\underset{(\%)}{\text { Total }}$} \\
\hline & $\begin{array}{c}<6 \\
f(\%)\end{array}$ & $\underset{(\%)}{6-<10}$ & $\underset{(\%)}{10-<15}$ & $\underset{(\%)}{\geq 15}$ & $\underset{(\%)}{\text { Male }} \underset{f}{f}$ & $\begin{array}{c}\text { Female } \\
\underset{(\%)}{f}\end{array}$ & \\
\hline Replete i & $\begin{array}{c}3 \\
(50.0) \\
\end{array}$ & $\begin{array}{c}15 \\
(46.8) \\
\end{array}$ & $\begin{array}{c}27 \\
(48.2) \\
\end{array}$ & $\begin{array}{c}2 \\
(33.3) \\
\end{array}$ & $\begin{array}{c}31 \\
(58.5) \\
\end{array}$ & $\begin{array}{c}16 \\
(34.0) \\
\end{array}$ & $\begin{array}{c}47 \\
(47.0) \\
\end{array}$ \\
\hline Depleted iron & $\begin{array}{c}3 \\
(50.0) \\
\end{array}$ & $\begin{array}{c}17 \\
(53.2) \\
\end{array}$ & $\begin{array}{c}29 \\
(51.8)\end{array}$ & $\begin{array}{c}4 \\
(66.7) \\
\end{array}$ & $\begin{array}{c}22 \\
(41.5) \\
\end{array}$ & $\begin{array}{c}31 \\
(66.0) \\
\end{array}$ & $\begin{array}{c}53 \\
(53.0) \\
\end{array}$ \\
\hline Total & $\begin{array}{c}6 \\
(100)\end{array}$ & $\begin{array}{c}32 \\
(100)\end{array}$ & $\begin{array}{c}56 \\
(100)\end{array}$ & $\begin{array}{c}6 \\
(100)\end{array}$ & $\begin{array}{c}53 \\
(100)\end{array}$ & $\begin{array}{c}47 \\
(100)\end{array}$ & $\begin{array}{c}100 \\
(100)\end{array}$ \\
\hline & \multicolumn{4}{|c|}{$\begin{array}{c}\mathrm{p}-\text { value }=0.9 \\
\chi^{2}=0.5, \mathrm{df}=3\end{array}$} & \multicolumn{2}{|c|}{$\begin{array}{c}\mathrm{p} \text {-value }=0.014 \\
\chi^{2}=5.9, \mathrm{df}=1\end{array}$} & \\
\hline
\end{tabular}

Source: Authors' estimations.

\section{Discussion}

Anemia is a term given to a pathological process in which erythrocyte hemoglobin $(\mathrm{Hb})$, hematocrit $(\mathrm{Ht})$ and the concentration of red blood cells per unit of volume are abnormally low compared to the peripheral blood parameters of a reference population. In normal individuals, hematocrit and hemoglobin levels vary in accordance with the phase of development of the individual, and as a function of hormonal stimulation, environmental oxygen pressure, age and gender (Jordão et al. 2009).

The overall prevalence of anemia among studied children $(1,828)$ in all districts under the present study was $37.9 \%$. Mild anemia accounted $22 \%$ and moderate anemia accounted $15.7 \%$. 
In developed countries, 4.3 to $20 \%$ of the population, depending on age and gender, are affected by iron deficiency anemia, while in developing countries these figures range from 30 to $48 \%$ (CDC 2002).

A recent Egyptian study on 300 children at Fayoum governorate demonstrated that $64 \%$ of the studied children had iron deficiency anemia with $20 \%$ mild, $41.7 \%$ moderate and $2.3 \%$ severe (AL Ghwass et al. 2015).

Comparison between different Egyptian localities could identify regional variations related to socio economic conditions. Fayoum is one of the poorest governorates in Egypt. The present work declared that anemia is a health problem in South Sinai, but other areas have a worse status.

Using data from the Egyptian Demographic and Health Surveys between 2000 and 2005 declared that the prevalence of anemia (defined as hemoglobin concentrations $<11 \mathrm{~g} / \mathrm{dL}$ ) increased from $37.04 \%$ to over $52 \%$ among Egyptian children between 12 months and 36 months of age (Austin et al. 2011).

In the present work, only residential location of the city and height for age percentile add significantly to the model prediction of anemia among screened children $(\mathrm{OR}=2.4,1.01$ respectively) ( $\mathrm{p}$-value $<0.05)$. This can explain the statistical significant difference observed in prevalence of anemia between different cities ( $p$-value $<0.05$ ) with higher prevalence in Sider and Nuweibaa $(45.3 \%)$ and $(43.7 \%)$, respectively. The aim of this study was to screen for iron deficiency anemia, we did not study any etiological factors. Furthermore, higher prevalence of anemia in certain areas means that they should have priorities for applying health education, supplementation or fortification programs to combat anemia in the future.

Age group 10-<15years had the least prevalence of anemia $(\mathrm{p}<0.0001)$. Children with history of consanguinity and those of Bedouin origin have less prevalence of anemia $(p=0.008)$. Gender has no effect $(p=0.6)$.

A Korean study illustrated that female had more IDA at age 15-54 years. However, other age groups showed no gender difference (Lee et al. 2014). This data is in accordance with our results.

It was found that children from low social class and those of low maternal educational level had a higher risk for IDA than other children in rural areas. Infants with IDA were found to consume food with low iron content reaching $50 \%$ below recommended daily allowance (AL Ghwass et al. 2015).

One of the most important factors determining iron deficiency anemia is inadequate diet with poor iron, micronutrients and vitamin content, leading to an insufficient intake of nutrients such as iron, folic acid, vitamin A, vitamin B12 and vitamin D. Multiple micronutrient deficiencies are still common worldwide and may be present at any age, hampering both physical and cognitive development (Kurpad et al. 2013). In addition to age, gender and physiological state, socioeconomic and nutritional status were also significant risk factors for IDA; low socioeconomic status, underweight, iron- or vitamin C-poor diets were all associated with IDA (Lee et al. 2014). In South Sinai, iron, vitamin $\mathrm{C}$ and vitamin $\mathrm{A}$ intakes were below required allowances (Ghanem et al. 2015). 
To reach a definitive diagnosis of iron deficiency anemia, in addition to performing a full blood count (hemoglobin, hematocrit, red blood cell count), ferritin and serum iron levels should be measured (Silva et al. 2002).

CBC proved that 129 out of 349 were anemic (36.96\%). Age group $10<15$ years have hemoglobin and hematocrit values above other age groups $(\mathrm{p}<0.002$ and $\mathrm{p}<0.04$, respectively). Anemia among Bedouins was $31 \%$ compared to $40 \%$ of urban origin. This data is consistent with results of pin prick $\mathrm{Hb}$ test that was mediated for 1,828 children.

Median serum ferritin in the present work was below 15 and transferrin saturation was below 20. In progress of iron deficiency, a sequence of biological and hematological events occurs. Serum ferritin (an indication for iron stores) decreases. It provides a relatively accurate estimate of body iron stores in absence of inflammatory disease. Transferrin percent saturation also decreases (Glader 2007).

Plasma ferritin levels decrease when there is a deficiency of iron that is not complicated by another concomitant disease. This reduction in ferritin occurs early, well before the abnormalities in hemoglobin levels, serum iron levels or in erythrocyte size become apparent (Paiva et al. 2000)

Patients with a serum ferritin concentration less than $25 \mathrm{ng}$ per $\mathrm{mL}(25$ mcg per L) have a very high probability of being iron deficient. The most accurate initial diagnostic test for IDA is the serum ferritin measurement. (Guyatt et al. 1992).

$53 \%$ of examined children had depleted iron stores. Females had higher rates than males $(\mathrm{p}=0.014)$. Older children $\geq 15$ years have more depletion but difference was not significant $(\mathrm{p}=0.9)$. Many literatures condemn adolescents to have more anemia than younger children. Change feeding habits with growth could be a factor. Menses for adolescent females might have a role. We aimed to screen for anemia in a descriptive way, we did not proceed to discuss etiological factors in this work.

Data of the present work and literature publications indicate that nutritional iron deficiency is quite prevalent among South Sinai children leading to this high prevalence of anemia (37.9\%). Presence of this high rates of iron deficiency anemia in spite of fortified school meal provided to children means that this meal is either inadequate or non palatable. Further evaluation for this meal should be carried on. Variation in different cities and effect of ethnic origin and consanguinity drive attention to nutritional habits in each city that augment or inhibit the occurrence of anemia.

\section{Conclusions}

Prevalence of anemia among South Sinai children proved to be $37.8 \%$. Anemic children were mild to moderate. This value comes within the developing world published data. Yet, this value is high enough to pay attention to this health problem to avoid well known hazard of anemia. 
Only residential city was proved to be a contributing risk factor for anemia in South Sinai children. Sidre and Nuweibaa cities should take the priority in proper iron supplementation and health education program. Other factors as age, gender and ethnic origin were not risk factors and did not cause increase in anemia prevalence.

$\mathrm{CBC}$ is the most accurate test for anemia evaluation. It measures hemoglobin and hematocrite. It shows the size of RBC (MCV), hemoglobin per $\mathrm{RBC}(\mathrm{MCH})$ and $\mathrm{MCHC}$. The present work showed that $\mathrm{CBC}$ results are comparable to pin prick testing regarding anemia screening. In addition, pin prick test is simple, cheap and could be done in remote areas.

Nutrition supplementation is provided to school children in South Sinai through biscuits distributed in schools. The value of this meal needs to be evaluated and the program needs updating.

\section{Acknowledgement}

This document has been produced with the financial assistance of EU. The contents of the document are the sole responsibility of Prof. Yamamah and can under no circumstances be regarded as reflecting the position of EU.

\section{References}

Abdelkader M (2005) The South Sinai Governorate Book: Egyptian Governorates Series. Cairo, Egypt: Centre for Political and Strategic Studies (p. 13).

Al Ghwass MM, Halawa EF, Sabry SM, Ahmed D (2015) Iron deficiency anemia in an Egyptian pediatric population: A cross-sectional study. Annals of African Medicine 14(1): 25-31.

Austin AM, Fawzi W, Hill AG (2012) Anaemia among Egyptian Children between 2000 and 2005: Trends and predictors. Maternal and Child Nutrition 8(4): 52232.

CDC-Centers for Disease Control and Prevention (2002) Iron deficiency, United States, 1999-2000. MMWR-Morbidity and Mortality Weekly Report 51(40): 8979.

Dawson-Saundersm B, Trapp RG (1994) Basic and Clinical Biostatistics (2nd ed.). Norwalk, Connecticut: Appleton \& Lange.

De Andrade Cairo RC, Rodrigues Silva L, Carneiro Bustani N, Ferreira Marques CD (2014) Iron deficiency anemia in adolescents: A literature review. Hospital Nutrition 1-29(6): 1240-9.

Ghanem KZ, Abdel-Aziz SA, Mahmoud MH, Mohamed MS, Yamamah GA (2015) Assessment of dietary iron, zinc, vitamins $\mathrm{A}$ and $\mathrm{C}$ intake in children and adolescents in South Sinai. Research Journal of Pharmaceutical, Biological and Chemical Sciences (forthcoming).

Glader B (2007) Identifying anemia. In Kliegman RM, Jenson HB, Behrman RE, Stanton BF (ed.) Nelson Textbook of Pediatrics. Saunders Elsevier, p. 2014-17.

Guyatt GH, Oxman AD, Ali M, Willan A, McIlroy W, Patterson C (1992) Laboratory diagnosis of iron-deficiency anemia: an overview. Journal of General Internal Medicine 7: 145-53. 
Jordão RE, Bernardi JLD, Barros Filho AA (2009) Prevalence of iron deficiency anemia in Brazil: A systematic review. Revista Paulista de Pediatria 27(1): 90-8.

Killip S, Bennett JM, Chambers MD (2010) Iron Deficiency Anemia. Downloaded from the American Family Physician Web site at www.aafp.org/afp. Copyright $\left({ }_{0}\right.$ 2010 American Academy of Family Physicians.

Korean Ministry of Health and Welfare (2013) Korean Health Statistics 2010: Korean National Health and Nutrition Examination Survey (KNHNES V-1). Retrieved from http://bit.ly/1RFr3L0. [Accessed: 1 May 2013]

Kurpad AV, Edward BS, Aeberli I (2013) Micronutrient supply and health outcomes in children. Current Opinion in Clinical Nutrition and Metabolic Care 16(3): 328-38.

Lee JO, Lee JH, Ahn S, Kim JW, Chang H, Kim YJ, Lee KW, Kim JH, Bang SM, Lee JS (2014) Prevalence and risk factors for iron deficiency anemia in the Korean population: results of the fifth Korea National Health and Nutrition Examination Survey. Journal of Korean Medical Science 29(2): 224-9.

Mclean E, Congswell M, Egli I, Woldyle D, de Bonist B. (2009) Worldwide prevalence of anemia, WHO Vitamin and Mineral Nutrition Information System 1993-2005. Public Health Nutrition, 12(4): 244-254.

Paiva AA, Rondó PHC, Guerra-Shinohara EM (2000) Parameters for the assessment of iron status. Revista de Saúde Pública 34(4): 421-6.

Silva GD, Franceschini CSC, Priori SE, Ribeiro SMR, Lima NMM, Maffia UCC (2002) Anemia ferropriva em crianças de 6 a 12 meses atendidas na rede pública de saúde do município de Viçosa, Minas Gerais [Iron deficiency anemia in children aged 6 to 12 months attending the public health system of Viçosa, Minas Gerais]. Brazilian Journal of Nutrition (2002) 12(1): 54-9.

Transferrin Saturation Calculation (2010). Retrieved from www.pubinfo.vcu.edu/ pathLabs/calc/transferrin.html.

Van Assendelft OW (1977) The assessment of hemoglobin. In Isak G, Lewis SM (ed.) Modern Concepts of Hematology. NY: New York Academic Press. (p.14).

WHO (2011) Haemoglobin Concentrations for the Diagnosis of Anaemia and Assessment of Severity. Vitamin and Mineral Nutrition Information System. Geneva, World Health Organization, 2011. Retrieved from http://bit.ly/1AIsFPJ. [Accessed 30 August 2014]

WHO (1989) Preventing and Controlling Anemia Through Primary Health Care: A Guide For Health Administrators and Program Managers. Geneva: World Health Organization. Retrieved from http://bit.ly/1ENPht2. 